\title{
石灰石添加自溶性ペレットの常温および低温度域還元性状*
}

\author{
土屋脩**.大槻健**. 杉山 健 ${ }^{* *}$ \\ 小野田 守**. 藤田 勇雄***
}

\section{Physical and Low Temperature Reducing Properties of Lime-fluxed Pellets}

\author{
Osamu Tsuchiya, Ken OHtuki, Takeshi Sugryama \\ Mamoru ONODA, and Isao FUJITA
}

\begin{abstract}
Synopsis:
This paper describes experimental results of physical and reducing properties of pellets up to $1100^{\circ} \mathrm{C}$ of reduction temperature as a function of basicity, $\mathrm{SiO}_{2}$ contents and indurating temperature during the addition of limestone. These properties are closely correlated to the bonding structures of indurated pellets which are classified into 6 types.

Those are hematite (A), hematite + low-basicity silicate slag (B), hematite +calcium ferrite (G), hematite +high basicity silicate slag + di-calcium silicate (D), A+B, and $\mathrm{C}+\mathrm{D}$ bonding structures.

A-type pellets have lower crushing strength and higher open porosity, swelling index and reduction degree, B-type ones have the highetst crushing strength and swelling index and the lowest open porosity and reduction degree, $\mathrm{G}$-type ones have the highest open porosity and reduction degree and the lowest swelling index, and D-type ones have much higher crushing strength and reduction degree and much lower swelling index.

Therefore, physical and reducing properties of pellets change remarkably by adding limestone.

Pellets with $(\mathrm{C}+\mathrm{D})$-bonding structures give the highest levels of crushing strength and reduction degree, and the lowest swelling index.
\end{abstract}

\section{1. 緒言}

最近の日本をはじめとする高炉の大型化，高能率化扝 よび高炉解体調查結果から, 高炉装入物に要求される性 状も従来の $1100^{\circ} \mathrm{C}$ 以下の高炬塊状帯に打敩強度, 被 還元性, 粉化性およびろくれ性以外に高温度域の軟化・ 溶解帯にお子る装入物の軟化・融着 - 溶融 - 滴下性状も 重要視され研究されつつある1) 3).

しかし, ペレットの常温性状掞よび高炉塊状带に対応 する還元性状がすべて究明されたわけではなく, 特に高 温性状との関連においてこの常温および低温度域還元性 状も重要視されるものと考えられる.

従来ペレットの自溶性化による性状変化については, 単一銘柄鉄鉱石を対象に 2,3 の性状に関した報告は見 られるが4) 8)，ペレットの各種性状と製造および配合条 件との関係を系統的に取り扱つた報告は少ない。
本報告は石灰石添加による自溶性ペレットの常温およ び低温度域還元性状 $\left(1100^{\circ} \mathrm{C}\right.$ 以下の温度域における還 元性状）と製造条件として塩基度， $\mathrm{SiO}_{2}$ 量および焼成 温度との関係を検討し，焼成ペレット中の結合組織別に 各性状の特徵を分類したものである.

\section{2. 実 験 方 法}

供試鉄鉱石はアフリカのアイボリーコースト産磁鉄精 鉱ならびにオーストラリアのハマスレー産赤鉄鉱の高品 位塊鉱である。これら供試鉄鈗石の粒度は前者の場合比 表面積 $1400 \mathrm{~cm}^{2} / \mathrm{g}$ であるのでそのまま供試し，後者は 塊鉱であるので鉄乳鉢および小型ボールミルでそれぞれ 粗砕・磨鉱し $3000 \mathrm{~cm}^{2} / \mathrm{g}$ とした. ペレット中の $\mathrm{CaO}$ および $\mathrm{SiO}_{2}$ 量の調整にはそれぞれ比表面積 $4000 \mathrm{~cm}^{2} /$ $\mathrm{g}$ に粉砕した石灰石および珪砂を用いた．使用原料の粉 砕粒度はペレットの性状に影響をおよぼす主要なる因子

* 昭和 46 年 10 月本会講演大会にて発表 昭和 54 年 8 月 10 日受付 (Received Aug. 10, 1979)

** (株) 神戸製鋼所中央研究所 (Central Research Laboratory, Kobe Steel, Ltd., 1-3-18 Wakinohama-cho Fukiai-ku Kobe 651)

*** (株) 神戸製鋼所中央研究所 理博 (Central Research Laboratory, Kobe Steel, Ltd.) 
Table 1. Chemical analysis of raw materials.

\begin{tabular}{|l|cccccccc|}
\hline \multirow{2}{*}{ Raw materials } & \multicolumn{7}{|c|}{ Chemical composition (\%) } \\
& $\mathrm{Fe}$ & $\mathrm{FeO}$ & $\mathrm{SiO}_{2}$ & $\mathrm{Al}_{2} \mathrm{O}_{3}$ & $\mathrm{CaO}$ & $\mathrm{MgO}$ & $\mathrm{S}$ & Ig.loss \\
\hline Ivory cost & 70.34 & 29.31 & 1.91 & 0.20 & 0.07 & 0.27 & 0.01 & - \\
Hamersley & 67.72 & 0.94 & 1.29 & 0.43 & 0.03 & 0.02 & 0.003 & 2.34 \\
Lime stone & - & - & 0.36 & 0.26 & 54.78 & 0.94 & - & 43.56 \\
Silica sand & - & - & 98.5 & 0.04 & 0.02 & 0.1 & - & 0.15 \\
\hline
\end{tabular}

の一つである．本試験では，(株) 神戸製鋼所・加古川ぺ レット工場に括ける粉砕工程を通過した原料の比表面積 值を参考にしてハマスレー鉱の此表面積を上述の值に設 定した．珪砂は鉄鉱石中に介在する脈石の代替として使 用したものであり，脈石拈よび石灰石は鉄鉱石よりも微 粉砕されやすいことから，珪砂抢よび石灰石の粒度は八 マスレー鉱よりも若干細かい比表面積值に設定した.

Table 1 にこれら供試原料の化学組成を示す.

アイボリーュースト精鉱とハマスレー鉱の混合比を重 量比で $30:$ ? にきめ, 焼成ペレット中の $\mathrm{SiO}_{2}$ 含量 2 , $4,6 \%$ について $\mathrm{CaO} / \mathrm{SiO}_{2}$ 比を 0, 0.5 1.5, 2.0 になるよ らに石灰石および珪砂の計算量を配合した．配合試料は 小型ドラムミキサーに装入し $1 \mathrm{~h}$ 混合して造粒原料を作 成した．造粒にはタイヤ型ペレタイザを用い散水，鉱石 の供給を交互に繰り返し直径約 $10 \mathrm{~mm}$ の生ペレットを 調整した。焼成にはシリコニット電気炉を用い $\mathrm{O}_{2}: \mathrm{N}_{2}$ =15:85の組成の混合ガス流通雾囲気下でステンレス製 バスケット中に装入した 50 ヶの生ペレットを $20 \mathrm{~min}$ 間昇温, 所定焼成温度で $15 \mathrm{~min}$ 間保持した後 $30 \mathrm{~min}$ か けて冷却した。焼成温度は $1200,1250,1300^{\circ} \mathrm{C}$ の 3 水準とした.

常温性状としては圧潰強度および全気孔率, 開気孔率 ならびに閉気孔率を測定した，圧潰強度の測定は焼成ぺ レット 10 ヶについて行い平均值をもつて圧潰強度と表 示した. 全気孔率はJIS の見掛比重測定法(JIS M 8716) により得た見掛比重值とピクノメーター法により得た真 比重值の差から算出した. 閉気孔率は広ロピクノメータ を用いペレットを粉砕せずそのままピクノメータに装入 し真比重測定法に従い，開気孔率を含んだ比重の測定値 と真比重值の差から算出した. 開気孔率は全気孔率と閉 気孔率との差として算出した.

低温還元性状としてとりあげた性状は，被還元性，還 元試験後圧潰強度およびふくれ指数である. この試験に は反応管内径 $43 \mathrm{~mm}$ の小型カンタル製堅型電気炉を用 い，ステンレス製バスケット中にペレットを一層に 5 ヶ 装入し，還元温度 $900,1000,1100^{\circ} \mathrm{C}$ の 3 段階でガス組 成 $\mathrm{CO}: \mathrm{N}_{2}=30: 70$ の還元ガスを $21 / \mathrm{min}$ で流し $1 \mathrm{~h}$ 還元した。還元前後の重量変化から還元率を, 還元終了
後のペレットの圧潰強度の平均值から還元試験後圧潰強 度を，また還元前後の体積変化からふくれ指数を求め た.

\section{3. 実 験 結 果}

\section{1 常温性状}

ペレットの塩基度, $\mathrm{SiO}_{2}$ 量および焼成温度を変化さ せた場合の圧潰強度の変化を Fig. 1 に，また全気孔率 拈よび開・閉気孔率を Fig. 2 に示す。

圧潰強度は塩基度に対して $\mathrm{CaO} / \mathrm{SiO}_{2}$ 比で $0.5 \sim 1.5$ に極大值を示すように変化する．ペレットの $\mathrm{SiO}_{2}$ 含量 の多い汪ど，また焼成温度の高い汪どその極大値は低塩 基度側に移行する，焼成温度の影響は，酸性ペレットで は焼成温度および $\mathrm{SiO}_{2}$ 量の増大に伴い圧潰強度は增大 するのに対し， $\mathrm{CaO} / \mathrm{SiO}_{2}$ 比が 0.5 以上になると $\mathrm{SiO}_{2}$ $2 \%$ の低シリカペレットは温度 $1250^{\circ} \mathrm{C}$ で焼成したも ので極大值が認められる. $\mathrm{SiO}_{2}$ 含量 $4 \%$ または $6 \%$ のペ レットでは焼成温度の上昇に伴つて圧潰強度が低下する 傾向を示す。つぎに $\mathrm{SiO}_{2}$ 量の影響についてみれば，酸 性扝よび $\mathrm{CaO} / \mathrm{SiO}_{2}$ 比で約 0.5 の低塩基性の配合試料 を低温度で焼成した石灰石添加ペレットでは， $\mathrm{SiO}_{2}$ 量 の増大に伴い圧潰強度は増大するが，高塩基度で高温度
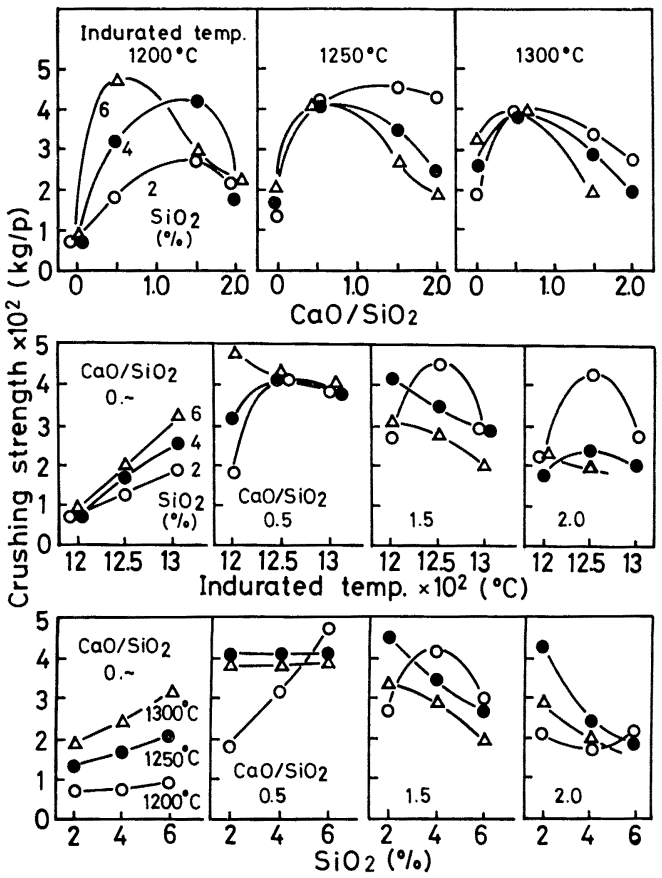

Fig. 1. Effects of $\mathrm{CaO} / \mathrm{SiO}_{2}$, indurated temp. and $\mathrm{SiO}_{2}$ contents on crushing strength of sampled pellets. 
焼成したペレットでは強度は逆に低下する傾向が認めら れる。

以上の結果から，一般に石灰石または珪砂等のスラグ 成分を増加するとペレットの圧潰強度は増大するが，こ れは鉄鉱石・脈石および石灰石間の反応で形成されたス ラグ相の鉱粒間結合補強効果のためと考えられる4)5). しかし $\mathrm{CaO} / \mathrm{SiO}_{2}$ 比または $\mathrm{SiO}_{2}$ 量を単純に増加すれ ば高強度を得られるのではなく, 焼成温度との関連にお いて最大強度を得る $\mathrm{CaO} / \mathrm{SiO}_{2}$ 比および $\mathrm{SiO}_{2}$ 量の所 定值がある. 高塩基度, 高 $\mathrm{SiO}_{2}$ 量で高温度焼成した場 合には逆に強度を低下しており，スラグ相の種類および 生成量によつても鉱粒の結合強度が変化するものと推察 される4). ともあれペレットを自溶性化することによ り，低温度で焼成しても王潰強度 $200 \mathrm{~kg} / \mathrm{p}$ 以上の満足 すべき性状のペレットを容易に製造可能と推察される.

Fig. 2 はペレットの気孔率について Fig. 1 と同様の 検討を行つたものである. 寸なわち全気孔率についてみ れば，焼成温度 $1250^{\circ} \mathrm{C}, \mathrm{SiO}_{2}$ 量 $4 \%$ および $6 \%$ のぺ レットでは $\mathrm{CaO} / \mathrm{SiO}_{2}$ 比 1.5 の塩基度において極大值 を示す以外は，いずれのペレットについても全気孔率は 塩基度の増大に伴つて増加し, その増加の度合は焼成温 度の上昇ならびに $\mathrm{SiO}_{2}$ 量の増大にともない著じるしく なる. 塩基度の変化に伴ら開 . 閉気孔率の変化の模様は 次のようである。すなわち閉気孔率は極大值を，また開

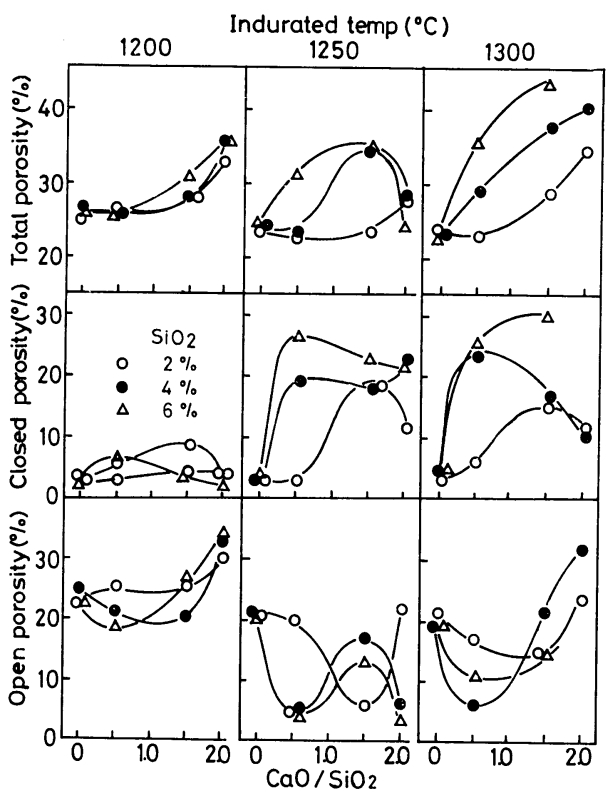

Fig. 2. Effects of $\mathrm{CaO} / \mathrm{SiO}_{2}$, indurated temp. and $\mathrm{SiO}_{2}$ contents on total, closed and open porosity of sampled pellets.
気孔率は極小值を示すように変化し，焼成温度および $\mathrm{SiO}_{2}$ 量の増加に伴いその変化度合は著しくなるのみな らず，極大・極小值の位置も低塩基度側に移行する傾向 にある。

全気孔率の変化の傾向からのみ判断すると, ペレット の石灰石添加による自溶性化はペレットを多孔質化し焼 結性の促進といら観点からはその効果が少ないように考 えられる. しかしこれは昇温加熱過程において石灰石中 の炭酸塩が解離し, 焼成初期にペレット外周部に液相ス ラグが形成し内部の気孔が閉鎖されたためである. した がつて閉気孔率と開気孔率の差違からも明らかなよらに 高塩基度, 高 $\mathrm{SiO}_{2}$ 量掞よび高温度焼成に対応する自溶 性ペレットでは少数の独立した大きな径の球状気孔が散 在するが, 結合部は非常に緻密であり, 酸性ペレットに おいてみられる多数の連続した気孔が散在してわずかに 鉱粒間にのみ結合が発達した組織とは明らかに異なる4).

ペレットの塩基度, $\mathrm{SiO}_{2}$ 量ならびに焼成温度による 圧潰強度打よび気孔率の变化を全体的に把握するため, 等圧潰強度曲線，等全気孔率曲線ならびに等閉気孔率曲 線の形で図示したのが Fig. 3 である.

等圧潰強度曲線からみられるように高圧潰強度を得る ために必要な $\mathrm{SiO}_{2}$ 量および $\mathrm{CaO} / \mathrm{SiO}_{2}$ 比には適当な 範囲があり，その範囲は焼成温度 $1250^{\circ} \mathrm{C}$ で最も広く $1300^{\circ} \mathrm{C}$ で最も狭い, 圧潰強度の最高值が得られる組成 は $\mathrm{CaO} / \mathrm{SiO}_{2}$ 比約 $1.0, \mathrm{SiO}_{2}$ 量約 $4 \%$ と推定される.

等全気孔率曲線についてみれば，温度 $1200^{\circ} \mathrm{C}$ およ び $1300^{\circ} \mathrm{C}$ の焼成では $\mathrm{CaO} / \mathrm{SiO}_{2}$ 比ならびに $\mathrm{SiO}_{2}$ 量 の増大に伴い全気孔率は増加し, 温度 $1300^{\circ} \mathrm{C}$ 焼成に おいてより両因子の影響が大きくなり，また全気孔率も $22 \%$ から $42 \%$ へと著しく増大する。焼成温度 1250

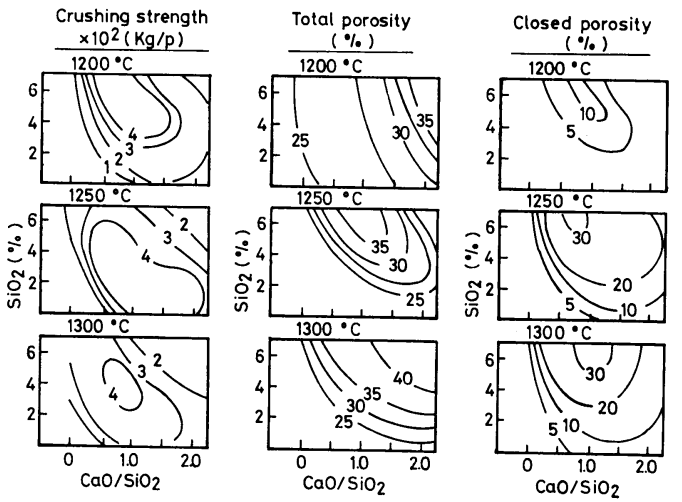

Fig. 3. Iso-crushing strength and -porosity curves in relation between $\mathrm{SiO}_{2}$ contents and $\mathrm{CaO} /$ $\mathrm{SiO}_{2}$ of sampled pellets. 


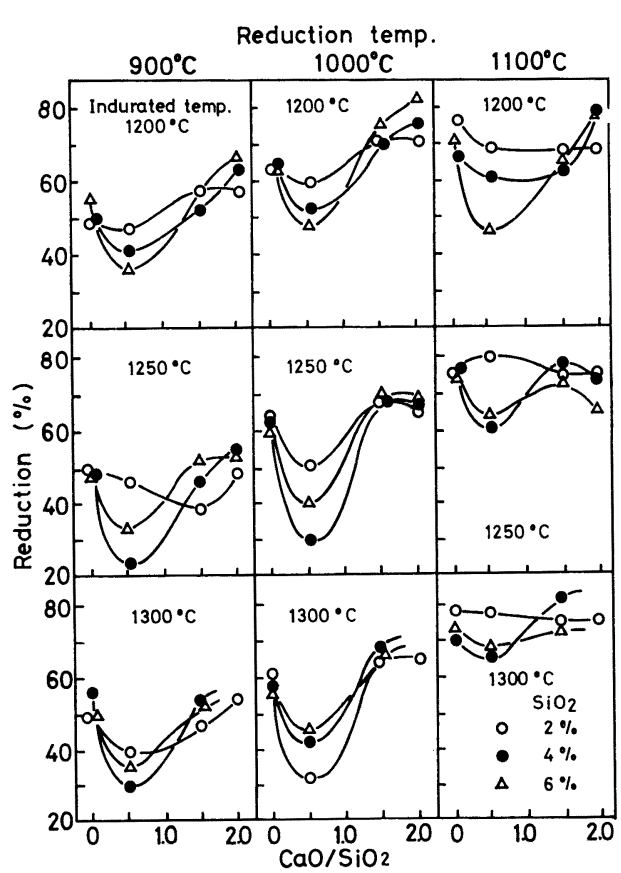

Fig. 4. Effects of $\mathrm{CaO} / \mathrm{SiO}_{2}$, indurated temp. and $\mathrm{SiO}_{2}$ contents on reducibility of sampled pellets.

${ }^{\circ} \mathrm{C}$ では実験範囲内に全気孔率の最高値を示唆する範囲 があり, それは $\mathrm{CaO} / \mathrm{SiO}_{2}$ 比 $0.7 \sim 1.5, \mathrm{SiO}_{2} \geqq 4.2 \%$ 付近と推測される.

等閉気孔率曲線は，焼成温度が高いほど $\mathrm{CaO} / \mathrm{SiO}_{2}$ 比, $\mathrm{SiO}_{2}$ 量の影響が顕著となり, 最高閉気孔率を示す範 囲は $\mathrm{CaO} / \mathrm{SiO}_{2}$ 比約 1.0 で $\mathrm{SiO}_{2}$ 0.5\%〜 1.25\%を中 心とする領域と考えられる.

\section{$3 \cdot 2$ 被還元性}

Fig. 4 は塩基度の被還元性におよぼす影響を $\mathrm{SiO}_{2}$ 量 をパラメータとして, 還元温度および焼成温度別に示し たものである。

全体的傾向として $\mathrm{CaO} / \mathrm{SiO}_{2}$ 比 0.5 で極少值を示 し, さらに $\mathrm{CaO} / \mathrm{SiO}_{2}$ 比が増大すると睘元率は顕著に 増大し，特に $\mathrm{SiO}_{2}$ が $4 \%$ 以上においてこの傾向はより 明確となる. $\mathrm{CaO} / \mathrm{SiO}_{2}$ 比が 0.5 のとさ還元率におよ ぼす各因子の影響が最も著しく, $1200^{\circ} \mathrm{C}$ 焼成試料では $\mathrm{SiO}_{2}$ 含量の増加に伴つて還元率は低下する。これに対 して $1250^{\circ} \mathrm{C}$ および $1300^{\circ} \mathrm{C}$ で焼成したペレットでは $\mathrm{SiO}_{2}$ 含量 $4 \%$ のとき還元率が最も低い. また当然のこ とながら各ペレットとも還元温度の上昇に伴つて還元率 は増大して括り, 温度 $1250^{\circ} \mathrm{C}$ および $1300^{\circ} \mathrm{C}$ で焼成 した $\mathrm{CaO} / \mathrm{SiO}_{2}$ 比が 0.5 のペレットは還元温度 900
${ }^{\circ} \mathrm{C}$ および $1000^{\circ} \mathrm{C}$ において低い還元率を示すにもかか わらず還元温度 $1100^{\circ} \mathrm{C}$ では高い還元率を示す.この $\mathrm{CaO} / \mathrm{SiO}_{2}$ 比 0.5 のペレットは, 後述するふくれ指数 が還元温度 $1100^{\circ} \mathrm{C}$ で著しく高い值を示す結果から考 えて, ふくれ現象による反応界面積の増大が還元率の增 大に寄与したものと推察されよう。

$\mathrm{CaO} / \mathrm{SiO}_{2}$ 比 0.5 を除外すると,酸性ペレットを石灰 添加ペレットと比較すると後者の方が還元率は大である が，焼成温度打よび還元温度が高いほどその差は小さ w.

以上述べたように, ペレットの還元性は塩基度, $\mathrm{SiO}_{2}$ 量および焼成温度等の製造条件により大きく変化する. これは製造条件を変えることにより，ペレットの気孔形 成状況および形成スラグ物質が変化するためである.

Fig. 5 はこの気孔形成状況すなわちペレットの反応界 面積に対応する開気孔率と還元率との関係を示したもの である．両還元温度に拈いて両者間には有意なる相関が あり，還元率は開気孔率の増大に伴つて増加する. 還元 温度が高くなるほどペレット細孔内ガス拡散抵抗の割合 が小さくなり還元率の開気孔への依存性は小さくなる. 還元温度 $900^{\circ} \mathrm{C}$ に打いて開気孔率 $25 \%$ より小さくな るほど $\mathrm{CaO} / \mathrm{SiO}_{2}$ 比 0.5 ペレット $\mathrm{CaO} / \mathrm{SiO}_{2}$ 比 1.5 および 2.0 ペレット間に還元率の差が生じている.これ は鉱粒結合部に形成したスラグ相の酸化鉄還元に対する 影響度の相違によるものと推察される。

Fig. 6 は還元試験後圧潰強度の塩基度による変化を示 したもので, ペレットの $\mathrm{SiO}_{2}$ 含量, 焼成温度および還

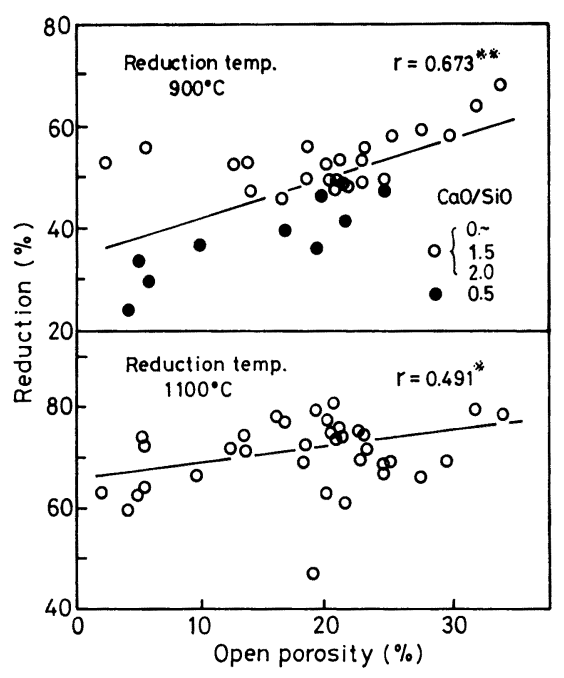

Fig. 5. Relation between reduction degree and open porosity of sampled pellets. 


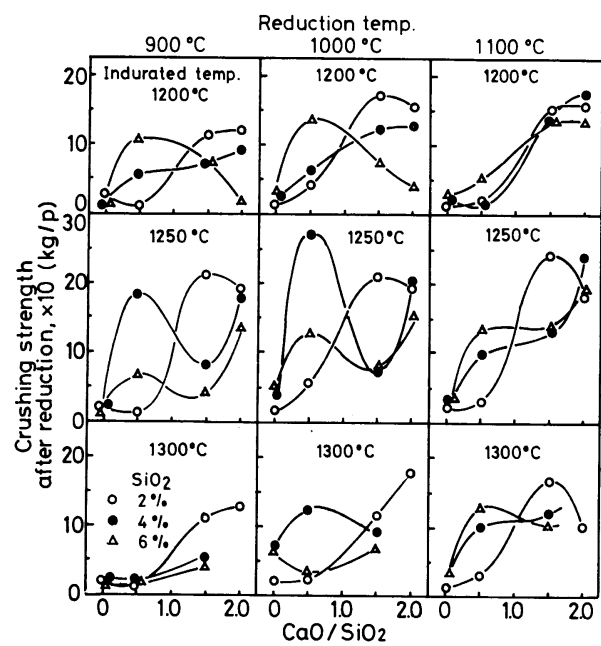

Fig. 6. Effects of $\mathrm{CaO} / \mathrm{SiO}_{2}$, indurated temp. and $\mathrm{SiO}_{2}$ contents on crushing strength after reduction of sampled pellets.

元温度を変えて行つた実験結果を図示したものである.

$\mathrm{SiO}_{2} 2 \%$ のペレットについてみると還元試験後圧潰 強度におよぽす塩基度の影響は焼成温度および還元温度 が異なつても，ほぼ同一の傾向を示している．すなわち $\mathrm{CaO} / \mathrm{SiO}_{2}$ 比 0.5 までは最大 $50 \mathrm{~kg} / \mathrm{p}$ と低強度を示 し, $\mathrm{CaO} / \mathrm{SiO}_{2}$ 比 1.5 以上に打いて急激に強度を増大 し $100 \mathrm{~kg} / \mathrm{p}$ 以上の值を示している. この傾向は次に述 ベるふくれ指数と塩基度との関係とほぼ逆の対応にあ る. $\mathrm{SiO}_{2} 4$ $6 \%$ のペレットでは, $\mathrm{SiO}_{2} 2 \%$ のペレッ トに比べて $\mathrm{CaO} / \mathrm{SiO}_{2}$ 比 0.5 のとき強度が増大するの に対し, $\mathrm{CaO} / \mathrm{SiO}_{2}$ 比 1.5 のペレットでは逆に強度が低 下寸る傾向にある.

このように還元試験後圧潰強度も製造条件により大き く変化するが, $\mathrm{CaO} / \mathrm{SiO}_{2}$ 比 0.5 でかつ低 $\mathrm{SiO}_{2}$ 量の ペレットを除外すれば，石灰石を添加し自溶性化するこ とによりほぽ $50 \mathrm{~kg} / \mathrm{p}$ 以上の強度を持つペレットを製 造することが可能である.

\section{3 ふくれ指数}

Fig. 7 にふくれ指数におよぼす塩基度の影響につい て，焼成温度，還元温度および $\mathrm{SiO}_{2}$ 量を変えて行つた 実験結果を示す.これらの図から明らかなように，全般 的には $2 \cdot 3$ の例外を除いてほとんどの曲線が $\mathrm{CaO} /$ $\mathrm{SiO}_{2}$ 比 0.5 に打いて極大を示す。 また極大值は $\mathrm{SiO}_{2}$ 量の増加に伴つて減少する.すなわちふくれ指数は低減 する傾向にある. 石灰石添加比の大きい $\mathrm{CaO} / \mathrm{Si}_{2} \mathrm{O}$ 比 1.5 および 2.0 のペレットのふくれ指数は著しく低く, 焼成温度, 還元温度や $\mathrm{SiO}_{2}$ 量の影響を受けない。また

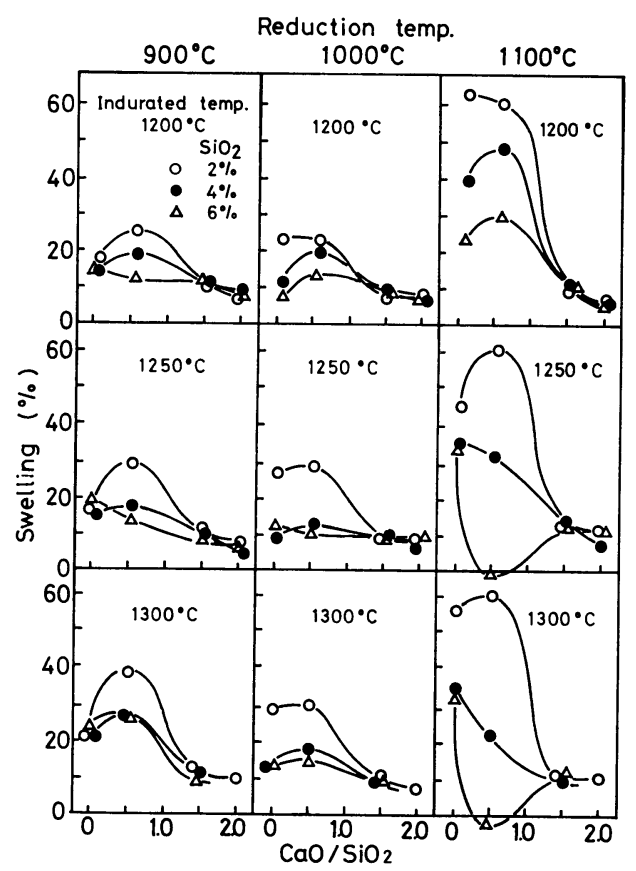

Fig. 7. Effects of $\mathrm{CaO} / \mathrm{SiO}_{2}$, indurated temp. and $\mathrm{SiO}_{2}$ contents on swelling value of sampled pellets.

$\mathrm{SiO}_{2} 6 \%$ で $\mathrm{CaO} / \mathrm{SiO}_{2}$ 比 0.5 組成の配合試料と温度 $1250^{\circ} \mathrm{C}$ 打よび $1300^{\circ} \mathrm{G}$ で焼成し，さらに温度 $1100^{\circ}$ C で還元すると極端な収縮がみられる.

還元温度 $900^{\circ} \mathrm{G}$ ならびに $1000^{\circ} \mathrm{C}$ の場合, 還元温度 のふくれ指数におよぼす影響は顕著でない。これに対し 還元温度 $1100^{\circ} \mathrm{C}$ になると低温度還元の場合と大きく 異なつたふくれ性をみることができる．この傾向は酸性 および $\mathrm{CaO} / \mathrm{SiO}_{2}$ 比 0.5 のペレットについて主にみら れ，前述の収縮を示した $\mathrm{CaO} / \mathrm{SiO}_{2}$ 比が 0.5 のペレッ トが還元温度上昇に伴つてふくれ指数を著じるしく低下 する場合を除いて，他のいずれのペレットとも還元温度 $1100^{\circ} \mathrm{C}$ に打いて著しくふくれ指数が増大している. $\mathrm{CaO} / \mathrm{SiO}_{2}$ 比 1.5 および 2.0 ではすでに述べたように 還元温度の影響はほとんどみられない。

Fig. 8 に還元時間に対するふくれ指数の変化曲線を示 す. 酸性ペレットでは還元時間 15〜30 min でふくれ指 数が極大に達し， $\mathrm{SiO}_{2}$ 量の多い汪ぞその後のふくれ指 数の低下度合が著しい．これに対して $\mathrm{CaO} / \mathrm{SiO}_{2}$ 比が 0.5 のペレットではふくれ指数の変化は潜伏期を持ち 最大值に達する時間が長く，徐々に増大する傾向を示 す.この組成のペレットは還元過程で発生する応力があ る程度畜積され，鉱粒の結合に関与するスラグ相が酸化 


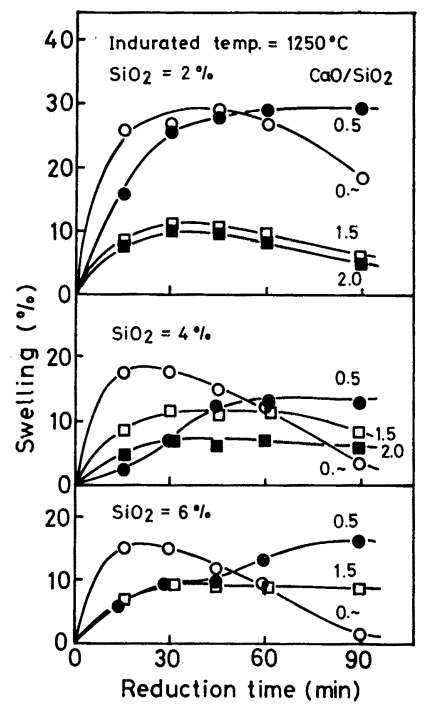

Fig. 8. Effects of $\mathrm{CaO} / \mathrm{SiO}_{2}$ and $\mathrm{SiO}_{2}$ contents on swelling behaviour of sampled pellets.

鉄の格子変態により発生した応力に耐えることが出来な くなつた時点で急速にふくれることを示唆している.

$\mathrm{CaO} / \mathrm{SiO}_{2}$ 比が 1.5 および 2.0 のペレットでは還元時 間約 $30 \mathrm{~min}$ でふくれ指数は最大になるが，その值は $10 \%$ 程度で低く, 低 $\mathrm{SiO}_{2}$ 量ではその後わずかにふく れ指数を低下するが高 $\mathrm{SiO}_{2}$ 量ではふくれ指数の変化は 見られず一定值を示す.

従来ふくれの現象としては, $\mathrm{Fe}_{2} \mathrm{O}_{3} \rightarrow \mathrm{Fe}_{1-\mathrm{y}} \mathrm{O}$ 一の還 元過程での格子変態からの鉱粒間結合の分離おょび鉱粒 自身の細化に基づく正常らくれと， $\mathrm{Fe}_{1-\mathrm{y}} \mathrm{O} \rightarrow$ 金属鉄一 の還元過程での繊維状金属鉄の生成による鉱粒間結合の 分離に基づく異常ふくれとがあると報告されている 12). 本供試ペレットは初期マルコナペレットにみられた ような $100 \%$ を越える異常ふくれは認められなかつた。 しかし比較的高いふくれ指数を示した酸性および $\mathrm{CaO} /$ $\mathrm{SiO}_{2}$ 比 0.5 ペレットの温度 $1100^{\circ} \mathrm{C}$ で還元したもの については, 明らかに繊維状金属鉄の生成が 観察され た.

以上の結果から, $\mathrm{CaO} / \mathrm{SiO}_{2}$ 比を 1.5 以上に調整する ことによりふくれ指数を著しく低下することが可能であ るが，ふくれ性は塩基度，スラグ量さらにはアルカリ成 分 ${ }^{13)}$ 等に影響され，特に脈石含有量の少ない鉱石を自溶 性ペレット化する場合には製造条件に注意を払う必要が あろう。

\section{4. 実験結果の考察}

\section{$4 \cdot 1$ 結合組織の分類}

ペレットは一般にその塩基度, $\mathrm{SiO}_{2}$ 量や焼成温度等 の変更により，常温および低温還元性状が影響をうける ことはすでに述べたと扤りである.すなわちぺレットの 構成鉱物の種類, その量ならびに構成鉱物の形成状況に よつて左右され，したがつて圧潰強度，ふくれ指数打よ び還元性はペレット中に出現した結合組織と密接なる関 係にあるものと考えられる.

石灰石添加による結合組織の变化は Fig. 9 の $\mathrm{Fe}_{2} \mathrm{O}_{3}$ $\mathrm{CaO}-\mathrm{SiO}_{2}$ 三元系状態図から推定される ${ }^{14)}$. すなわち石 灰石添加ペレットではペレット構成鉱物は焼成過程でま ず状態図上の低融点組成の融液を一部生成する。この初 期融液の生成領域は上記状態図から 2 つ領域に分けら れる. 1 つはタプI領域として示したカルシウムフェ ライト系融液組成領域であり，他はタイプII 領域と表示 した珪酸塩系融液組成領域である15)16)。したがつて本実 験配合条件下では， $\mathrm{CaO} / \mathrm{SiO}_{2}$ 比 0.5 においてはm·p= $1204^{\circ} \mathrm{C}$ のタイプII の共晶点付近の低塩基度珪酸塩系大 ラグの，また $\mathrm{CaO} / \mathrm{SiO}_{2}$ 比 1.5 以上の試料を $1200^{\circ} \mathrm{C}$ の温度で焼成した場合にはタイプのカルシウムフェラ イトの, $\mathrm{CaO} / \mathrm{SiO}_{2}$ 比 1.5 以上に拈いて $1250^{\circ} \mathrm{C}$ おび $1300^{\circ} \mathrm{G}$ 焼成した場合にはタイプIのカルシウムフェラ イトとタイプII の高塩基度側共晶点付近の珪酸塩系スラ グの初期融液が生成する。 この高塩基度側の共晶点の $\mathrm{m} \cdot \mathrm{p}$ は $1214^{\circ} \mathrm{C}$ および $1230^{\circ} \mathrm{C}$ にみられる。

さらに焼成時間を長くすると, この初期融液と酸化鉄

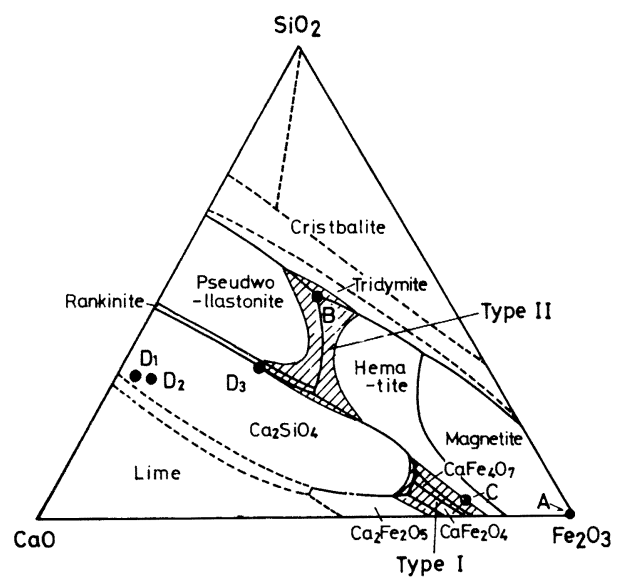

Fig. 9. $\mathrm{CaO}-\mathrm{SiO}_{2}-\mathrm{Fe}_{2} \mathrm{O}_{3}$ system and chemical composition of each bonding structure of sampled pellets. 


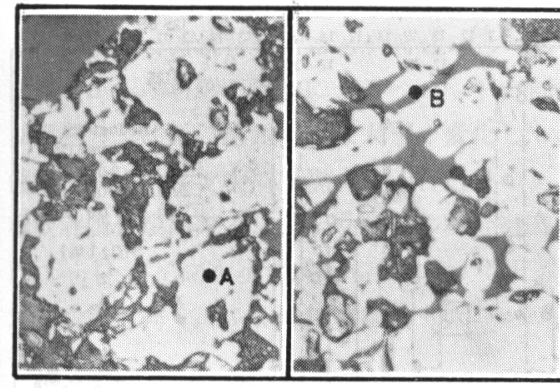

Type : A

Type : B

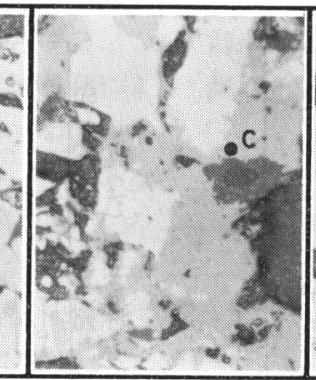

Type : C

Types boding structure

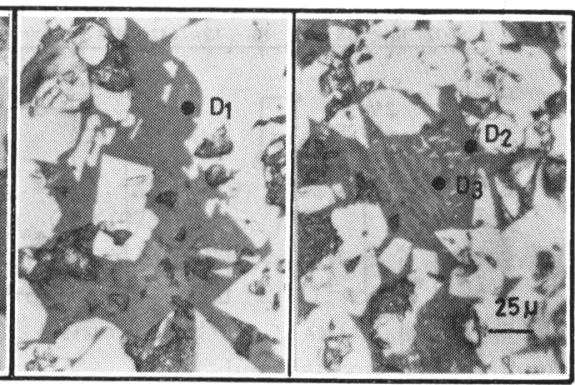

Type : D

Photo. 1. Microstructure of pellets with typical bonding structure $(\times 200 \times 9 / 10)$.

および他のスラグ成分間の反応が進行して融液生成量が 増加する。 その結果 $\mathrm{CaO} / \mathrm{SiO}_{2}$ 比 0.5 ではタイプIIの 低温塩基度領域組成の久の結合組織となる。 $\mathrm{CaO} / \mathrm{Si}_{2} \mathrm{O}$ 比 1.5 扎よび 2.0 で温度 $1200^{\circ} \mathrm{C}$ で焼成したものは タイプ I の領域組織の, 温度 $1250^{\circ} \mathrm{C}$ 物よび $1300^{\circ} \mathrm{C}$ で焼成したものはタイプ IIの高塩基度領域組成扣よびカ ルシウムシリケートとタイプIの領域組成の混合結合組 織となる ${ }^{17)}$.この混合組織中タイプ Iのカルシウムフェ ライト組織は昇温加熱過程で生成するもので, 特に低 $\mathrm{SiO}_{2}$ 含量で高塩基度の場合に出現しやすいものと考光 られる。

以上に述べた状態図に基づく検討を参照にして, 供試 ペレットの顕微鏡組織観察からペレットの結合組織を以 下の 6 種類に分類した.

A：へマタイトの固相拡散結合, B：へマタイト+低 塩基度珃酸塩スラグ溶融結合, $\mathrm{C}$ ：ヘマタイト+カルシ ウムフェライト結合, D：へマタイト十高塩基度理酸塩 スラグおよびカルシウムシリケートスラグの溶融結合, ならびに A+B 拈よび $\mathrm{C}+\mathrm{D}$ の混合結合組織の合計 6 種類である.

Photo. 1 は上記のA, B, G㧊よびDタイプの代表的顕 微鏡組織を示したものである. Photo. 1中にマークした 各点のX線マイクロアナライザーによる分析結果はFig. 9 の $\mathrm{Fe}_{2} \mathrm{O}_{3}-\mathrm{CaO}-\mathrm{SiO}_{2}$ 三元系状態中の $\mathrm{A}, \mathrm{B}, \mathrm{C}, \mathrm{D}_{1}$, $\mathrm{D}_{2}$ 尔よび $\mathrm{D}_{3}$ 点に対応する.

このように各タイプの結合相の鉱物組成はすでに述べ た状態図からの検討とほぼ一致したものであるが，ただ タイプ Dの結合スラグ相のみが本実験の焼成温度では溶 融し得ない高融点を持つダイカルシウムシリケート相が 形成していることになる。

これについては次のように説明されよら。すなわちタ イプ Dの結合組織を有するペレットは高塩基性であり, したがつて前述のようにタイプII 領域に位置する高塩基
度側共晶点付近の初期融液が生成し，続いてこの融液中 に $\mathrm{CaO}$ 成分が固溶して固相ダイカルシウムシリケート を形成する。このため融液中の $\mathrm{CaO}, \mathrm{SiO}_{2}$ 成分量が減 少し共晶点付近の組成を維持与るように再び $\mathrm{CaO}, \mathrm{SiO}_{2}$ 成分の融液中への溶解沶よび $\mathrm{Fe}_{2} \mathrm{O}_{3}$ の晶出が起こる結 果, 共晶点付近融液 $\rightarrow$ ダイカルシウムシリケート形成が 繰り返され，焼成ペレットの組織として暗灰色のダイカ ルシウムシリケート十高塩基度珃酸塩系スラグまたは灰 色の高塩基度珪酸塩系スラグが観察される。 $\mathrm{CaO}$ 打よ び $\mathrm{SiO}_{2}$ 量, 括よび焼成ならびに冷却条件により上記組 織の内前者のみのものと前 2 者の縞状混合組織のものが 得られる。屯た $\mathrm{D}$ 秥よび $\mathrm{C}+\mathrm{D}$ タイプの結合組織中には 焼成扰よび冷却中に晶出したへマタイトまたはマグネタ イトの縞状組織の存在もみられる. 定性的には以上の上 らに推察されるが，詳細についてはさらに検討が必要で ある・

\section{$4 \cdot 2$ 結合組織と常温性状および低温還元性状}

6 種類に分類した結合組織を持つ各々のペレットにつ いて，常温性状として圧潰強度および気孔率をまた低温 還元性状として還元率沶よびらくれ指数の各值を整理し た結果をそれぞれ Fig. 10〜Fig. 13 に示す.

これらの図から評価した各結合組織を持つペレットの 性状の特徴は次のとおりである.

タイプ A : ヘマタイトの固相桩散結合主体の酸性ペレ ットで, 珪砂は未涬化で残留して沶り液相の生成量は少 ない. 圧潰強度, 全気孔率拈よび閉気孔率は一般に低 く, 開気孔率は反対に高い. らくれ指数特よび還元率は いずれも高いのが特徵である.

タイプ $\mathrm{B}: \mathrm{CaO} / \mathrm{SiO}_{2}$ 比 0.5 付近のペレットで, 溶融 スラグ相が酸化鉄鉱粒間を局部的に充填するように発達 し，压潰强度は最も高いレベルにある。全気孔率および 開気孔率は $\mathrm{SiO}_{2}$ 量，焼成温度により広範囲に変化す る。高 $\mathrm{SiO}_{2}$ 量执よび高い焼成温度で製造したペレット 


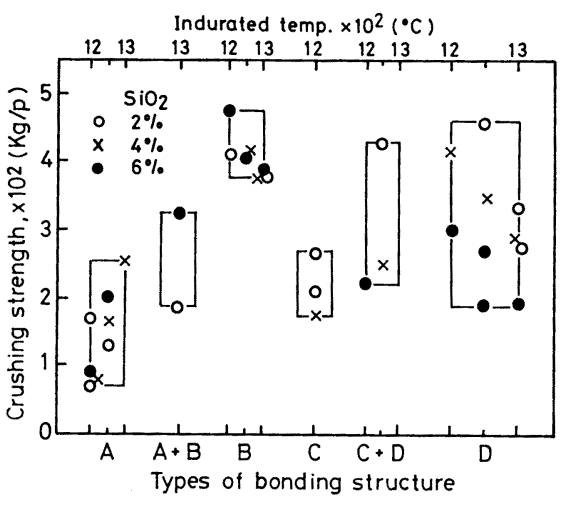

Fig. 10. Change of crushing strength by types of bonding structure of sampled pellets.

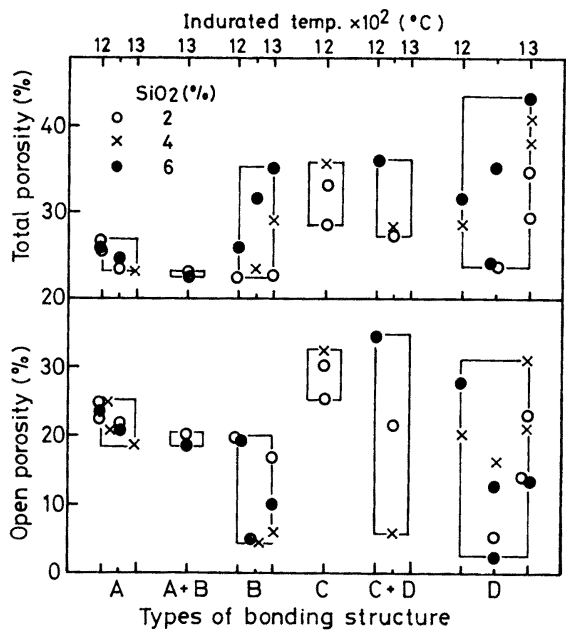

Fig. 11. Change of total and open porosity by type of bonding structure of sampled pellets.

はスラグ生成量が多くなり全気孔率および閉気孔率は高 く, 開気孔率は低い，ふくれ指数はタイプ $\mathrm{A}$ と同程度で 高く, 特に低 $\mathrm{SiO}_{2}$ 量で著しく高い值を示す. $\mathrm{SiO}_{2} 2$ $\%$ および $4 \%$ では還元温度 $1100^{\circ} \mathrm{C}$ で高值を示すが， さらに $\mathrm{SiO}_{2}$ 量が増加して $6 \%$ になると還元温度上昇に ともなつてふくれ指数が著しく低下する。これは $\mathrm{FeO}$ $\mathrm{CaO}_{-} \mathrm{SiO}_{2}$ 三元系状態図から推測されるように，還元過 程で生成したウスタイトと他のスラグ成分が反応して $1100^{\circ} \mathrm{C}$ 以下の融点を持つオリビン系の液相を形成した ためと考えれば納得できる。還元率は還元温度 $900^{\circ} \mathrm{C}$ および $1000^{\circ} \mathrm{C}$ において最も低い值を示すが，還元温 度 $1100^{\circ} \mathrm{C}$ ではタイプ $\mathrm{A}$ と同程度の高い值を示す。

タイプ $\mathrm{G}$ ：供試鉱石中に $\mathrm{Al}_{2} \mathrm{O}_{3}$ 成分量が少ないた

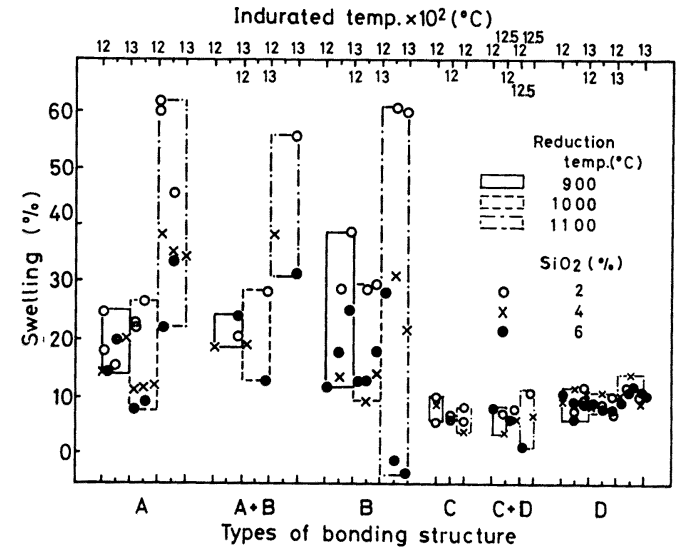

Fig. 12. Change of swelling value by type of bonding structure of sampled pellets.

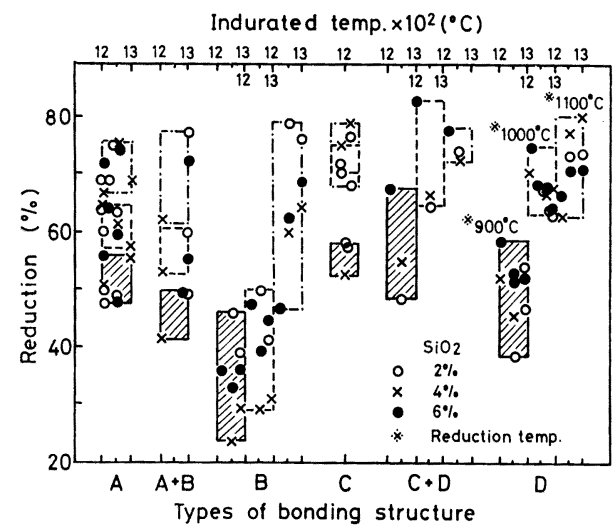

Fig. 13. Change of reduction degree by type of bonding structure of sampled pellets.

め，このタイプの組織を示すぺレットの製造条件は限定 され, $\mathrm{SiO}_{2} 2 \%$ で $\mathrm{CaO} / \mathrm{SiO}_{2}$ 比 1.5, 2.0 および $\mathrm{SiO}_{2}$ $4 \%$ で $\mathrm{CaO} / \mathrm{SiO}_{2} 2.0$ の温度 $1200^{\circ} \mathrm{C}$ で焼成したぺレ ットであつた。 このタイプの結合組織を持つペレット は，压潰強度は酸性ペレットよりわずかに高い程度でむ しろ低いレベルにあり，全気孔率拈よび開気孔率は高 い。しかし閉気孔率の形成はほとんど認められない。る くれ指数は著しく低く，還元率は高い。

タイプD：液相が十分に発達した組織を示し，圧潰強 度はタイプ $\mathrm{B}$ に次いで高い。各気孔率は $\mathrm{SiO}_{2}$ 量拉よび 焼成温度によつて変化するが，焼成温度の影響が強く $1250^{\circ} \mathrm{C}$ 焼成に拈いて全気孔率および開気孔率は最子低 い值を，閉気孔率は最も高い值を示す傾向にある.ふく れ指数は著しく低く，還元率はタイプ $\mathrm{A}$ および $\mathrm{C}$ よりも わずかに低いが，タイプB と比較すると著しく高い。

タイプ $\mathrm{A}+\mathrm{B}$ 㧊よびタイプ $\mathrm{C}+\mathrm{D}$ の給合組織を持つ 
ペレットはそれぞれ $\mathrm{A}, \mathrm{B}$ および $\mathrm{C}, \mathrm{D}$ タイプのペレ ットの中間の性状を示すことが図から明らかである.

以上から，石灰石添加によるペレットの自溶性化によ り常温および低温還元性状は大きく変化し，これら性状 值は焼成ペレット中に出現する結合組織のタイプである 程度評価分類出来る. 上記 6 分類の結合組織のタイプの 内 $\mathrm{C}+\mathrm{D}$ タイプを示すペレットに扣いて圧潰強度, 被還 元性は最も高く，ふくれ指数は最も低いレベルの值を持 つ.

\section{5. 結言}

ペレットに要求される性状として，従来高炉装入時ま でのハンドリング性，高炬シャフト部までの治金性状を 対象として，常温圧潰強度 $250 \mathrm{~kg} / \mathrm{p}, \mathrm{JIS}$ 還元率 $55 \%$ 以上，JIS ふくれ指数 $14 \%$ 以下の輸入ペレットに対す る品質規格の 1 例がある ${ }^{18)}$. 当試験結果から判断すると タイプ B の結合組織を有するペレット以外は石灰石添加 により高度に上記品質規格を満足するペレットを製造可 能である。

ペレットの石灰石添加自溶性化において，常温および 低温還元性状は塩基度, $\mathrm{SiO}_{2}$ 量および焼成温度等の製 造条件により種々変化するが，これら性状はペレット中 に出現する結合組織と密接なる関係にあり，この結合組 織は大きく 6 分類される．この中でへマタイトの固相拡 散結合以外にカルシウムフェライトの固相拡散拈よび高 塩基度珃酸塩スラグ（およびカルシウムシリケート）の 溶融結合組織を有するペレットに拈いて常温圧潰強度 および還元率は最も高く，ふくれ指数は最も低い值を示 与.

しかしこの C+D タイプの結合組織を有するペレ ットが高炉装入物として最適とはいえない。特に日本の ように他に焼結鉱および塊鉱石を混合使用する場合に は，これら装入物の性状との関連および高炉操業条件を 十分に考虑してペレットは製造・使用するべきものであ り，これらの条件に適合したペレットの種類を選択すべ きものであろう。
おわりに，本研究を遂行するにあたり適切な御助言， 御指導を賜つた京都大学工学部治金学科真嶋宏教授に感 謝の意を表します。

\section{交献}

1) 斧 勝也，肥田行博，重見彰利，児玉惟孝：鉄と 鋼，61 (1975) 6, p. 777

2) $S$. Kondo, $M$. Sugata, and $T$. Sugiyama: Proc. ICSTIS, 11 (1971), p. 36

$3) Y$. Ohmori and $Y$. Takahashi: Agglomeration 77, Proc. International Symposium on Agglomeration, 1 (1977) p. 286 (AIME, New York)

4 ) 藤井成美，田村節夫，田口和正，国井和扶，西田 礼次郎：鉄と鋼，54（1968）12，p. 1241

5 ) P. Barnabe and $S$. $S$. Palella: International Iron and Steel Congress, Düsseldorf, (1974)

6 ) $H . A$. Kortman and $O . P$. Burghardt: Rev. Met., (1976), p. 626

7 ) C. F. Kaiser, T. J. Roberts, and I. $A$. Thomson : Society of Mining Engineers, AIME, 525 (1972), p. 439

8 ) G. Thaning: LKAB News, Special Report, Oct, (1974)

9 ) R. L. Bleifuss: Society of Mining Engineers, AIME, 247 (1970), p. 225

10) L. Granse: Proc, ICSTIS, 11 (1971), p. 45

11) $H$. A. Kortmann, $O . P$. Burgharot, $B . M$. Grover, and $K$. КосH: Society of Mining Engineers, AIME, 254 (1973), p. 184

12) 石光章利，菅原欣一：鉄と鋼，54（1968）4, p. 277

13) 中沢孝夫，佐々木稔，伊藤 薰，近藤真一：鉄々 鋼，58 (1972) 8, p. 1039

14) $B$. Phillips and $A$. Muan : J. Amer. Ceram. Soc., 42 (1959) p. 413

15）小島鴻次郎, 永野恭一, 稲角忠弘, 片 志男, 品 田功一：鉄と鋼，56(1970)，p. 1789

16）高橋愛和，石井正夫，林田由美子，稲角忠弘：東 北大学選鉱製錬研究所栄報，32 (1976)， p. 75

17）松野二三朗：鉄と鋼，64 (1978) 10，p. 1499

18）科学技術庁資源調查所資料第 22 号：鉄鉱石供給 に関する基礎資料，(1969)，p. 102 [科学技術庁 資源調査所] 